Ann. Biol. anim. Bioch. Biophys., 1978, 18 (1), 167-174.

\title{
Calcemia regulation in the vitamin $D$ deficient growing pig
}

\author{
par A. POINTILLART, J. M. GAREL *, L. GUEGUEN
}

With the technical assistance of Colette COLIN

Station de Recherches de Nutrition, I.N.R.A.

78350 Jouy-en-Josas, France

* Laboratoire de Physiologie du Développement, Université P. ef M. Curie

9 quai St. Bernard, 75230 Paris Cedex 05, France.

Summary. Calcemia regulation in the vitamin D deficient growing pig.

Four young growing pigs deficient in vitamin D since birth showed hypocalcemia, hypomagnesemia and hypophosphatemia. Hypocalcemia and hypophosphatemia were higher after a deficiency of 3 months than of 2 months. Calcitonin and parathyroid hormone kinetics were observed for 1 month, either on 2 pigs with a 1-month deficiency or on 2 with a 2-months deficiency. Plasma PTH content increased concomitantly as plasma calcitonin decreased. Plasma PTH content remained within the normal limits known for the piglet ; this could be related to hypomagnesemia, which was more severe than hypocalcemia. The respective roles of CT and PTH are discussed as a function of time. Mathematical analysis suggested a possible adaptation of the calcemic regulatory mechanism in the piglet.

\section{Introduction.}

Clinical studies have suggested that secondary hyperparathyroidism may play a fundamental role in the evolution of human nutritional rickets (Taitz and de Lacy, 1962). Elevated concentrations of immunoreactive parathyroid hormone (PTH) were detected in the plasma of children with nutritional rickets (Joffe ef al. 1972). Serum calcium and PTH did not correlate with the degree of severity of rickets, but there was a negative correlation between these two variables (Arnaud, Stickler and Haworth, 1976). Conflicting results were reported in hypophosphatemic vitamin D- resistant rickets ; they showed no change (Arnaud, Glorieux and Scriver, 1971 ; Fanconi, Fischer and Prader, 1974) or elevated values (Lewy ef al., 1972). In animals, the effects of vitamin D deficiency on plasma calcitonin (CT) and PTH concentrations are unknown ; the present report investigates this aspect in young pigs, using radioimmunoassays for CT and PTH.

\section{Material and methods.}

Animals. Two pregnant sows were isolated and kept in darkness the whole gestation period; they received a normal commercial diet without added vitamin $D$. 
After birth, the piglets were allowed to suckle normally until weaning; they were then given a semi-synthetic diet (table 1) deficient in vitamin D and containing 0.9 p. 100 calcium, 0.6 p. 100 phosphorus and 0.2 p. 100 magnesium. Two piglets of each litter were maintained in metabolic stalls in darkness during approximately one month. Infrared lamps were used during food distribution. Two animals from the same litter were killed after 2 months (C and D) and the two others after 3 months of vitamin $D$ deficiency (A and B). A chronically-implanted catheter was fitted to collect blood samples twice daily from the jugular vein 2 hours and 7 hours after the morning meal. Samples intended for hormone assays were collected under peptidase inhibitors (Iniprol, Laboratoires Choay, Paris, France). After centrifugation at $4{ }^{\circ} \mathrm{C}$, plasma samples were frozen at $-30^{\circ} \mathrm{C}$ until hormone assays.

\section{TABLE 1}

Semi-synthefic dief without vifamin $D$ for piglets

Main ingredients (p. 100)

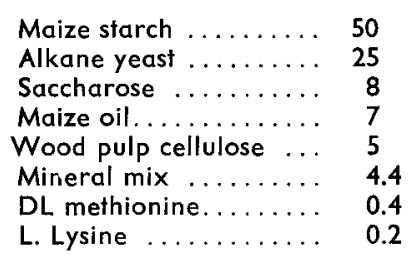

Mineral mix (p. 100)

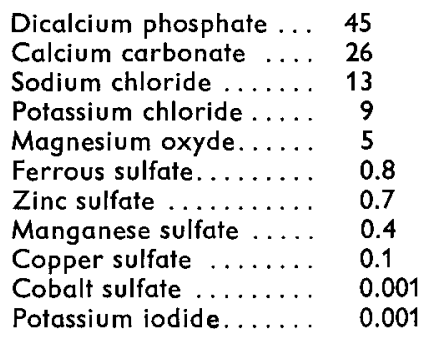

Vitamin mix for $1 \mathrm{~kg}(\mathrm{~g})$

Calcium pantothenate ..

Riboflavin ...........

Ascorbic acid ........

Nicotinamid .........

B $12(100 \mathrm{mg} / \mathrm{kg}) \ldots \ldots$

Choline $(25$ p. 100) $\ldots . \quad 200$

Methionine ........... 100

Vitamin A .......... 20

Glucose .......... q.s.p.

Plasma analysis. Plasma calcium was measured by flame photometry (Eppendorf) and plasma magnesium by atomic absorption spectrophotometry (IL 151). Plasma inorganic phosphorus was estimated by colorimetry (Chen, Toribara and Warner, 1956).

Plasma CT levels were measured by radioimmunoassay in a system already described in detail (Garel, Care and Barlet, 1974 ; Garel, Savajol and Barlet, 1976). This assay involved the use of purified porcine CT (Lot K600-072F-2; 116 MRC units/ $\mathrm{mg}$; Armour Pharmaceutical Co., Kankakee, Illinois, USA) for iodination through the chloramine-T method of Hunter and Greenwood (1962). The ${ }^{125}$-labelled porcine CT was purified by gel filtration on Sephadex-G50 fine. Specific activities of 200$300 \mu \mathrm{Ci} / \mu \mathrm{g}$ were achieved routinely. The same batch of purified porcine $\mathrm{CT}$ was also used as a standard. An antiserum (GP $2_{4}$ ) obtained in a guinea-pig against porcine $C T$ was used at a final dilution of $1: 3000$; the tubes were incubated in an equilibrium system at $4{ }^{\circ} \mathrm{C}$, and after 6 days were phase-separated on talcum powder.

The plasma PTH levels were also measured by radioimmunoassay using a bovine system already described (Garel and Barlet, 1976) which cross reacted with porcine PTH. Purified bovine PTH (bPTH 1-84, a gift of Drs. J. A. Parsons and J. M. Zanelli, M. R. C., London, England) was labelled with ${ }^{125}$ using the chloramine-T method (Hunter and Greenwood, 1962) and purified through gel filtration on Sepha- 
dex-G 50 fine. Standard curves were calibrated with pure bovine PTH (bPTH 1-84, a gift of Dr. G. D. Aurbach). An antibody, obtained in a goat against partially purified bovine PTH, was used at a final dilution of $1: 8000$. Since it did not cross-react with the synthetic bovine 1-34 fragment, this antibody showed specificities directed against the carboxyl terminal part of the PTH molecule. After incubation for 6 days at $4{ }^{\circ} \mathrm{C}$ in an equilibrium system, the bound and the free labelled fractions were separated by adsorption on plasma-coated charcoal. The results were expressed in ng equivalents bovine PTH/ml of plasma.

Statistical analysis. The results were statistically analyzed on a computer. Each parameter was plotted against time. Linear correlations between parameters were checked; their relative importance in the total variation of the experiment (principal components analysis, Roux, 1977) and the differences in the parameters between pigs or litters (discriminant analysis) were studied using DISPOP and FACTIS programs (Roux, 1977 ; Biometrie, INRA). Detailed mathematical analysis will be published elsewhere and this report only presents the main results. The daily means as a function of time, as well as all individual values (morning and afternoon values for two pigs), are shown on the figures.

\section{Results.}

Plasma calcium, magnesium and inorganic phosphorus levels. Low plasma calcium levels were observed in vitamin D-deficient pigs (fig. 1) ; hypocalcemia was more
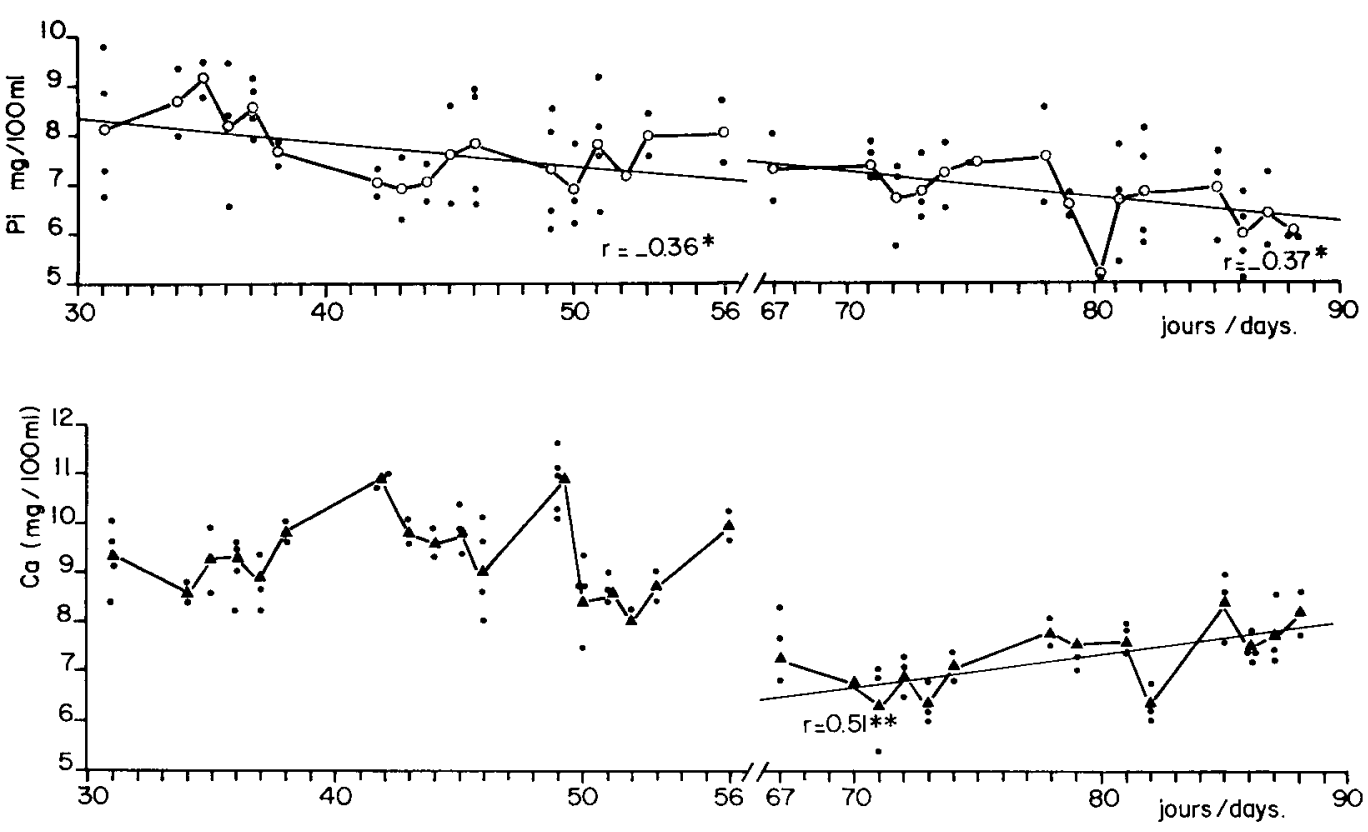

FIG. 1. - Influence of vitamin $D$ deficiency duration on calcemia and phosphatemia $(P i)$ in growing pigs. Regression lines were fitted on curves only when significant. $r$ : linear correlation, ${ }^{*} P<0,05$, $* * \mathrm{P}<0.01$. 
severe in animals with more than 2 months of deficiency. In pigs of the same age, the calcemia was $10-11 \mathrm{mg} / 100 \mathrm{ml}$ as opposed to $7-9 \mathrm{mg}$ in vitamin D-deficient animals (table 2). Low plasma magnesium levels were also observed in vitamin D-deficient pigs (about $1 \mathrm{mg} / 100 \mathrm{ml}$ ) (Table 2) as compared to those found in pigs of the same age (means range : $1.8-2.2 \mathrm{mg} / 100 \mathrm{ml}$ ). Very large magnesemia variations occurred as a function of time (limits : $0.56-2.16 \mathrm{mg} / 100 \mathrm{ml}$ ). A positive correlation appeared between calcemia and magnesemia in all vitamin D-deficient pigs $(r=0.42, P<0.01)$. Plasma inorganic phosphorus decreased progressively with time (fig. 1) and a significant negative correlation was observed. Severe hypophosphatemia occurred in vitamin D-deficient pigs (table 2) as compared to $10-11 \mathrm{mg} / 100 \mathrm{ml}$ normal values in pigs of the same age.

TABLE 2

Mean plasma levels of calcium, inorganic phosphorus $(\mathrm{Pi})$, magnesium, PTH and CT Comparisons between periods of vitamin $D$ deficiency

\begin{tabular}{|c|c|c|c|c|c|}
\hline \multirow[b]{2}{*}{ Pigs } & \multicolumn{3}{|c|}{$\begin{array}{l}\text { Period from } 31 \text { to } 52 \text { days } \\
\text { of vitamin } D \text { deficiency }\end{array}$} & \multicolumn{2}{|c|}{$\begin{array}{l}\text { Period from } 67 \text { to } 88 \text { days } \\
\text { of vitamin } D \text { deficiency }\end{array}$} \\
\hline & C & & $D$ & A & B \\
\hline $\begin{array}{l}\mathrm{Ca}(\mathrm{mg} / 100 \mathrm{ml}) \ldots \ldots \ldots \\
\mathrm{Pi}(\mathrm{mg} / 100 \mathrm{ml}) \ldots \ldots \ldots \\
\mathrm{Mg}(\mathrm{mg} / 100 \mathrm{ml}) \ldots \ldots \ldots \\
\mathrm{PTH}(\mathrm{ng} / \mathrm{ml}) \ldots \ldots \ldots \ldots \\
\mathrm{CT} \quad(\mathrm{ng} / \mathrm{ml}) \ldots \ldots \ldots \ldots\end{array}$ & $\begin{array}{l}9.08 \pm 0.25 \\
8.35 \pm 0.24 \\
1.16 \pm 0.10 \\
2.08 \pm 0.10 \\
1.51 \pm 0.25\end{array}$ & $\begin{array}{l}9.50 \\
7.56 * \\
1.10 \\
1.98 \\
1.18\end{array}$ & $\begin{array}{l} \pm 0.16 \\
\pm 0.18 \\
\pm 0.12 \\
\pm 0.10 \\
\pm 0.14\end{array}$ & $\begin{array}{l}7.24 \pm 0.16^{* *} \\
6.51 \pm 0.24 * * \\
1.29 \pm 0.15 \\
1.90 \pm 0.08 \\
3.12 \pm 0.20^{* *}\end{array}$ & $\begin{array}{l}7.23 * * \pm 0.19 \\
6.89 * * \pm 0.25 \\
1.00 * \pm 0.09 \\
2.09 \pm 0.10 \\
2.82 * * \pm 0.37\end{array}$ \\
\hline
\end{tabular}

** Significantly different $(P<0.01)$ from pigs $C$ and $D$.

* Significant difference $(P<0.05)$ between pigs $C$ and $D$ or $A$ and $B$.

\pm Standard error of mean.

Plasma calcitonin and parathyroid hormone levels. A negative correlation was observed between CT and PTH (pigs $C$ and $D:-0.28, P<0.05$; pigs $A$ and $B$ : - 0.33, $P<0.01$ ) since plasma CT levels decreased and plasma PTH content increased simultaneously as a function of time (fig. 2,3). Plasma CT levels were greater in pigs deficient for more than 2 months than in those with a 1-month deficiency (fig. 3), but regression lines were very different when litter was considered $(Y=-0.05 x+3.4$ for pigs $C$ and $D$, and $Y=-0.12 x+12.1$ for pigs $A$ and $B$ ). This might express a «litter effect » rather than a « time effect».

Main statistical results. The first two principal components (PC) represented 50 p. 100 of the total variation. On the PC1 of one-month deficient pigs $C$ and D (32 p. 100), time and PTH contrasted with CT, and secondarily with phosphatemia. The PC2 (22 p. 100) mainly concerned calcemia and magnesemia, which were close to one another. On PC1 in pigs A and B (29 p. 100), deficient for 2 months, time, calcemia and magnesemia contrasted with CT. For these pigs, PTH appeared only on the PC 2 and contrasted with magnesemia, CT and calcemia, magnesemia and CT being of the same order. Thus, the « PTH variate » on the PC1 became negligible in pigs with more 
than 2 months of deficiency as compared to 1-month deficient pigs, whereas the « CT variate » was present in both cases. « $\mathrm{Ca}$ and $\mathrm{Mg}$ variates 》 were very close on both PC1 (A and B) and PC2 (C and D). In all cases, time was the most determinative variate.

In discriminant analysis of all parameters (time, $\mathrm{Ca}, \mathrm{Mg}, \mathrm{Pi}, \mathrm{CT}, \mathrm{PTH}$ ) of all the pigs $A, B, C, D$, the following variates were significant : time $(F=176.46)$, calcemia $(F=41.58), C T(F=16.84)$, phosphatemia $(F=10.90)$, magnesemia $(F=3.35)$. Only PTH variate was not significant (degrees of freedom : $n=78$ ). Using litter discriminant analysis, there was no significant effect on any variates except that of $\mathrm{Mg}$ for pigs $A$ and $B$ and of $\mathrm{Pi}$ for pigs $C$ and $D$. In conclusion, time was the most important discriminant variate, followed by calcemia.

\section{Discussion.}

The decrease in plasma concentrations of $\mathrm{Ca}, \mathrm{Mg}$ and $\mathrm{Pi}$ was probably the result of poor intestinal absorption during vitamin D-deficiency, as already demonstrated in mini pigs (Miller ef al., 1965). However, in our experiments, hypomagnesemia was more severe than hypocalcemia ; for pigs $C$ and $D$, the mean shift was 50 and 13 p. 100, respectively, of normal values. This may explain the normal PTH levels observed, the mean level being about $2 \mathrm{ng} / \mathrm{ml}$ (table 2) in the 4 animals, in spite of clinical symptoms of tetany and osteodystrophy. Rickets mortality rate was 17 p. 100 for animals of the same litter. It has been shown that chronic hypomagnesemia in humans inhibited PTH synthesis (Suh et al., 1973), and that PTH release was impaired (Anast ef al., 1976). Estep ef al. (1969) have suggested that the action of PTH on target organs and cyclic AMP formation was impaired by Mg deficiency. Moreover, vitamin $D$ deficiency in our experiments induced 11 and 35 p. 100 drops, respectively, in the $\mathrm{Ca}$ and $\mathrm{Mg}$ contents of dry bone (Pointillart, unpublished data). Thus, vitamin D deficiency might induce $\mathrm{Mg}$ deprivation which, in furn, would decrease PTH synthesis and its action on target organs. Bone $\mathrm{Ca}$, however, was inversely correlated to the duration of vitamin $D$ deficiency $(r=0,47, P<0.01$, Pointillart, unpublished data). This last observation might indicate that bone resorption is enhanced. Plasma PTH levels increased with time and the discontinuity observed in this process (fig. 2) can be explained by a «pig effect » since the slopes of the curves are similar (slope $C D a=0.03$, slope $A B a=0.02$ ), individual variations always being important in this species. The fact that PTH was not a significant discriminant variable in the mathematical analysis confirms this.

The principal components analysis and discriminant analysis indicate that $C T$ decrease is more sensitive to hypocalcemia and hypomagnesemia than PTH increase (CT shift from 7.1 to $0.8 \mathrm{ng} / \mathrm{mg}$, PTH shift from 1.35 to $3.5 \mathrm{ng} / \mathrm{mg}$ ). These data confirm a previous report on pigs fed a low calcium diet where CT decreased with no significant change in PTH (Pointillart, Gueguen and Garel, 1977).

Some other factors may be involved in PTH secretion in vitamin D-deficient pigs since no correlation was found between $\mathrm{Ca}$ and PTH or between $\mathrm{Ca}$ and CT in contrast to the findings reported with a low Ca diet (Pointillart et al., 1977). The parathyroid gland might be stimulated by the association of hypocalcemia and hypomagnesemia ; 
the relationship between these factors was brought out by mathematical analysis. The correlation between PC2 and the variates were of the same order $(C T=0.61$, $\mathrm{PTH}=-0.71, \mathrm{Ca}=0.51, \mathrm{Mg}=0.61$ ), and there was always a correlation between $\mathrm{Ca}$ and $\mathrm{Mg}$. It is well known that plasma $\mathrm{Mg}$ affects PTH and $\mathrm{CT}$ secretion in ruminants (Care, 1967) ; it might be the same in pigs. The negative correlation between plasma $C T$ and PTH in vitamin D-deficient pigs suggests an interaction between these two hormones, as already shown with other diets (Pointillart et al., 1977).

Contrary to other experiments, we have not observed significant differences in plasma concentrations of samples collected 2 and 7 hours after the morning meal. Bone mobilization under PTH is vitamin D-dependent (Harrison and Harrison, 1964), and this hypothesis might explain why calcemia did not normalize after 3 months of deficiency in spite of a trend to elevated values (fig. 1).

Normal plasma PTH concentrations were seen in vitamin D-deficient pigs. However, hyperparathyroidism was described in human by Joffe et al. (1972) and early hyperparathyroidism was observed in bi-nephrectomized pigs (Garel et al. unpublished data) in which the source of 1.25 dihydroxycholecalciferol was suppressed. This may be due to hypomagnesemia, as mentioned before. Our experiments suggest also that plasma calcium regulation may change as a function of time, since the statistical analysis showed that PTH variate disappears from PC1 for pigs after more than 2 months of vitamin $D$ deficiency. This and the results described before indicate a possible adapiation in pigs.

\section{Conclusion.}

Vitamin D deficiency during 2 or 3 months in pigs affected CT and PTH regulation of calcemia. Normal PTH ranges are observed in spite of a significant tendency to increase either between 1 and 2 months or between 2 and 3 months. This could be due rather to a severe hypomagnesemia than to hypocalcemia. Principal components analysis, as well as discriminant analysis, are discussed, suggesting adaptation of calcemia regulation in pigs as a function of time. As in previous work reported, it seems that CT and $\mathrm{Mg}$ play important roles in the pig species.

Réunion Groupe Développement INRA/Productions animales Montpellier, 17-18 mai 1977.

Acknowledgements. - We whish to thank Ms. Colette Roux for the help she gave on the statistics. We also wish to thank Ms. Catherine Briand for the figures and Mr. Gauthier for his care of the animals. We are particularly grateful to Mr. Jean Choay who kindly furnished the Iniprol.

This study was partially supported by ATP $n: 2417$ of the CNRS.

Résumé. 4 jeunes porcs en croissance carencés en vitamine $D$ depuis leur naissance présentent une hypocalcémie, une hypomagnésémie et une hypophosphatémie. L'hypocalcémie et l'hypophosphatémie sont plus importantes après 3 mois de carence qu'après 2 mois. La cinétique de la calcitonine ef de la parathormone suivie durant un mois, soit sur 2 porcs carencés depuis 1 mois, soit sur 2 porcs carencés depuis 2 mois, fait apparaître 
une croissance du taux plasmatique de parathormone corrélée avec une décroissance de celui de calcitonine. Les teneurs du plasma en PTH restent dans les limites normales connues pour le porcelet, ce qui est peut-être en relation avec une hypomagnésémie plus sévère que l'hypocalcémie. Les rôles relatifs de la CT et de la PTH sont discutés en fonction du temps. L'analyse mathématique laisse suggérer une possible adaptation du mécanisme de régulation de la calcémie chez le porcelet.

\section{References}

ANAST C. S., WINNACKER J. L., FORTE L. R., BURNS T. W., 1976. Impaired release of parathyroid hormone in magnesium deficiency. J. clin. Endocrinol. Metab., 42, 707-717.

ARNAUD C. D., GLORIEUX F., SCRIVER C. R., 1971. Serum parathyroid hormone in $X$ linked hypophosphatemia, Science, 173, 845-848.

ARNAUD S. B., STICKLER G. B., HAWORTH J. C., 1976. Serum 25-hydroxy vitamin D in infantile rickets. Pediatrics, 57, 221-225.

CARE A. D., 1967. Magnesium homeostasis in ruminants. World Rev. Nufr. Diet., 8, 127-142.

CHEN P. S., TORIBARA T. Y., WARNER H., 1956. Microdetermination of phosphorus. Analyt. Chemistry, 28, 1756-1758.

ESTEP H., SHAW W. A., WALTINGTON C., HOBE R., HOLLAN W., TUCKER S. G., 1969. Hypocalcemia due to reversible hypomagnesemia and parathyroid hormone unresponsiveness. J. clin. Endocrinol. Metab., 21, 842-848.

FANCONI A., FISCHER J. A., PRADER A., 1974. Serum parathyroid hormone concentrations in hypophosphatemic vitamin D resistant rickets. Helv. paediat. Acta, 29, 187-194.

GAREL J. M., BARLET J. P., 1976. A radioimmuno assay for bovine parathyroid hormone. J. Physiol. (Paris), 72, 249-257.

GAREL J. M., CARE A. D., BARLET J. P., 1974. A radioimmunoassay for ovine calcitonin : an evaluation of calcitonin secretion during gestation, lactation and fœtal life. J. Endocr., 62, 497509.

GAREL J. M. SAVAJOL H., BARLET J. P., 1976. Plasma immunoreactive calcitonin levels in pregnant ewes and their lambs. Biol. Neonate, 28, 207-218.

HARRISON H. E., HARRISON H. C., 1964. The interaction of vitamin D and parathyroid hormone on calcium phosphorus and magnesium homeostasis in the rat. Metabolism, 13, 952-958.

HUNTER W. M., GREENWOOD F. C., 1962 . Preparation of 131/-labelled human growth hormone of high specific activity. Nature, Lond, 194, 495-496.

JOFFE B. I., HACKENG W. H. L., SEFTEL H. C., HARTDEGEN R. G., 1972. Parathyroid hormone concentrations in nutritional rickets. Clin. Sci., 42, 113-116.

LEWY J. E., CABANA E. C., REPETTO H. A., CANTERBURY J. M., REISS E., 1972. Serum parathyroid hormone in hypophosphatemic vitamin D resistant rickets. J. Pediat., 81, 294-300.

MILLER E. R., ULLREY D. E., ZUTAUT C. L., HOEFFER J. A., LUECHE R. W., 1965. Mineral balance studies with the baby pig : effects of dietary vitamin D2 level upon calcium, phosphorus and magnesium balance. J. Nutr., 85, 255-259.

POINTILLART A., GUEGUEN L., GAREL J. M., 1977. Calcitonine, parathormone ef déséquilibre phospho-calcique alimentaire chez le porc. 283-288. Journées Rech. Porcine en France, Institut Technique du Porc, Paris.

ROUX C., 1977. Programmes DISPOP et FACTIS, documentation interne (77.18 et 77.15) Biométrie INRA, Jouy-en-Josas.

SUH S. M., TASHJIAN A. H., MATSUO N., PARKINSON D. K., FRAZER D., 1973. Pathogenesis of hypocalcemia in primary hypomagnesemia : normal end-organ responsiveness to parathyroid hormone impaired parathyroid gland function. J. clin. Invest., 52, 153-160.

TAITZ L. S., DELACY C. D., 1962. Parathyroid function in vitamin D resistant rickets. Pediatrics, 30, 875-892. 